\title{
Article
}

Mycosphere

\section{Reaction of some apple cultivars to Diplodia bulgarica in Iran}

\author{
Hanifeh S, Zafari D and Soleimani MJ
}

Department of Plant Protection, Faculty of Agriculture, University of Bu Ali Sina, P.O. Box 65178-38695, Hamedan, Iran

Hanifeh S, Zafari D, Soleimani MJ 2017 - Reaction of some apple cultivars to Diplodia bulgarica in Iran. Mycosphere 8(2), 1253-1260, Doi 10.5943/mycosphere/8/2/9

\begin{abstract}
In recent years, Diplodia bulgarica A.J.L. Phillips, J. Lopes \& S.G. Bobev was identified as the main causal agent of apple tree decline in Iran. This fungus causes stem and trunk cankers, dieback, bark discoloration, gummosis, scaling-off of the bark and fruit rot in the west and northwest apple orchards of Iran. The disease was often prevalent in trees more than 15-years-old that were suffering from environmental stresses such as drought and nutrient deficiency. To evaluate the response of apple tree cultivars to this pathogen, six commercial cultivars (Golden Delicious, Red Delicious, Granny Smith, Red Starking, Braeburn, and Gala) and three local cultivars (Golab, Qara Yapragh, and Turkaman) were assessed under field conditions. The results confirmed that all cultivars are susceptible to Diplodia bulgarica, but mean lesion lengths differed significantly between cultivars $(\mathrm{P}=0.01)$. The largest lesions were observed on Braeburn, Red Delicious, and Red Starking cultivars, thus these cultivars were considered to be the most susceptible. Lesion lengths on Qara Yapragh, Turkaman, and Golden Delicious were significantly smaller than on all other cultivars and these were considered as moderately resistant to Diplodia bulgarica in Iran. To our knowledge, this is the first report on the response of apple tree cultivars to this devastating pathogen.
\end{abstract}

Key words - diplodia canker - gummosis - susceptible

\section{Introduction}

Apple (Malus domestica), is an important fruit crop that economically is known as a major agricultural product in Iran. Apple is cultivated in many areas of Iran and with a production of 3.4 million metric ton in 2014 it is the most important fruit crop. West Azerbaijan Province with 26\% is the most important apple production area in Iran (Ahmadi et al. 2015). Many pathogenic fungi have been recorded on apple trees. Botryosphaeriaceae with a cosmopolitan distribution (Denman et al. 2000) are common pathogens associated with various diseases on a wide host range of grasses, lichens and different woody plants such as apple (Barr 1987, Slippers \& Wingfield 2007, Phillips et al. 2013). In many cases, they have been described as endophytes or opportunistic pathogens associated with environmental stresses including high temperature and water stress (Denman et al. 2000, Slippers \& Wingfield 2007, Liu et al. 2012, Slippers et al. 2013).

In recent years, 23 genera have been recognized in this family including Diplodia (Dissanayake et al. 2016). Diplodia with more than 1000 species is known to be pathogen, endophytes and saprophytes on a wide range of mainly woody plants and has been found in association with different disease symptoms such as canker, gummosis, fruit rot, dieback and twig 
blight (Crous et al. 2006, Phillips et al. 2007, 2012, Slippers \& Wingfield 2007, Lazzizera et al. 2008, Abdollahzadeh et al. 2013). So far, several Diplodia species including D. bulgarica, D. intermedia, D. malorum, D. mutila, D. pseudoseriata and D. seriata have been characterized as pathogens on apple trees in different countries (Stevens 1933, Trapman et al. 2008, Phillips et al. 2012, Hanifeh et al. 2013, 2014, Delgado-Cerrone et al. 2016, Farr \& Rossman 2016, Sessa et al. 2016). Moreover, pathogenicity of D. intermedia, D. malorum, D. mutila, D. pseudoseriata and D. seriata have been studied on various trees including apple (Stevens 1933, Laundon 1973, Brown \& Britton 1986, Proffer \& Jones 1989, Brown-Rytlewski \& McManus 2000, Úrbez-Torres 2011, Hanifeh et al. 2013, 2014, Delgado-Cerrone et al. 2016, Sessa et al. 2016).

Susceptibility of shoots, fruits and leaves of different apple cultivars to D. seriata has been evaluated in some countries (Foster 1937, Borovinova 2006). It has already been shown that susceptibility of apple cultivars was influenced strongly by the rootstock (Borovinova 2006). In the past, the natural infection of apple buds to D. seriata also was investigated (Beisel et al. 1984). Moreover, the relative sensitivity of 23 apple cultivars to black rot disease (D. seriata) in the field and experimental conditions, was surveyed and it was found that apple cultivars have different responses (Biggs \& Miller 2004). In addition, the susceptibility of apple cultivars was assessed to other Botryosphaeriaceous fungi, such as B. dothidea, and it became known that trunk susceptibility is associated with cultivar, isolate and inoculation site (Latorre \& Toledo 1984). In Iran, based on morphological and molecular studies, the main causal agent of apple trees decline, especially in West Azerbaijan and Kermanshah Provinces, was isolated and identified as Diplodia sp. (Hanifeh et al. 2010b, Arzanlou \& Bakhshi 2012) and Diplodia bulgarica (Ketabchi \& Ghosta 2013, Nourian et al. 2013). Also, its pathogenicity has been considered on various trees including apple (cv. Golden Delicious) (Hanifeh et al. 2010a, Ketabchi \& Ghosta 2013, Nourian et al. 2013, Abdollahzadeh 2015). But it was uncertain if this fungus can attack different apple cultivars that are grown in Iran. Thus, the aim of present study was to evaluate the reaction of six commercial and three local apple tree cultivars to D. bulgarica.

\section{Materials \& Methods}

\section{Isolation and Identification}

During spring and summer of 2009, infected apple twigs, fruits, and trunk cankers were collected from apple orchards in the west (Kermanshah Province) and northwest (West Azerbaijan Province) of Iran (Fig. 1a-d). Severe damage was observed under environmental stresses such as drought and cold, especially in over 15-year-old orchards. In this survey, 91 fungal isolates were obtained from infected apple trees tissues, and all were used for morphological studies. After DNA extraction of an isolate, ribosomal DNA fragment amplified with ITS1 and ITS2 primers (White et al. 1990) was sequenced. The nucleotide sequence was used for BLAST searches with ex-type isolate sequences in GenBank. Isolates maintained at the Iranian Research Institute of Plant Protection (Tehran, Iran).

\section{Pathogenicity tests and Cultivars reaction trials}

Pathogenicity tests were carried out on potted 2-years-old apple seedlings ( $c v$. Golden Delicious) using the representative isolates from cankers and the most virulent isolate (IRAN 2727C) was used for the cultivars reaction trials.

In order to evaluate the apple tree cultivars reaction against the fungus, in July to September 2016, six commercial cultivars (Golden Delicious, Red Delicious, Granny Smith, Red Starking, Gala, and Braeburn) and three local cultivars (Golab, Qara Yapragh, and Turkaman) which were grafted on seedling rootstocks, were inoculated. The bark was surface sterilized with $70 \%$ ethanol and then a $5 \mathrm{~mm}$ plug was cut from the bark and replaced with a $5 \mathrm{~mm}$ plug of fungal mycelium from 7-d-old culture. The inoculated area was wrapped with parafilm to retain moisture. Agar plugs without fungal mycelium were used in the controls. The bark of the inoculated area was removed and the lesion lengths recorded after 8 weeks. 


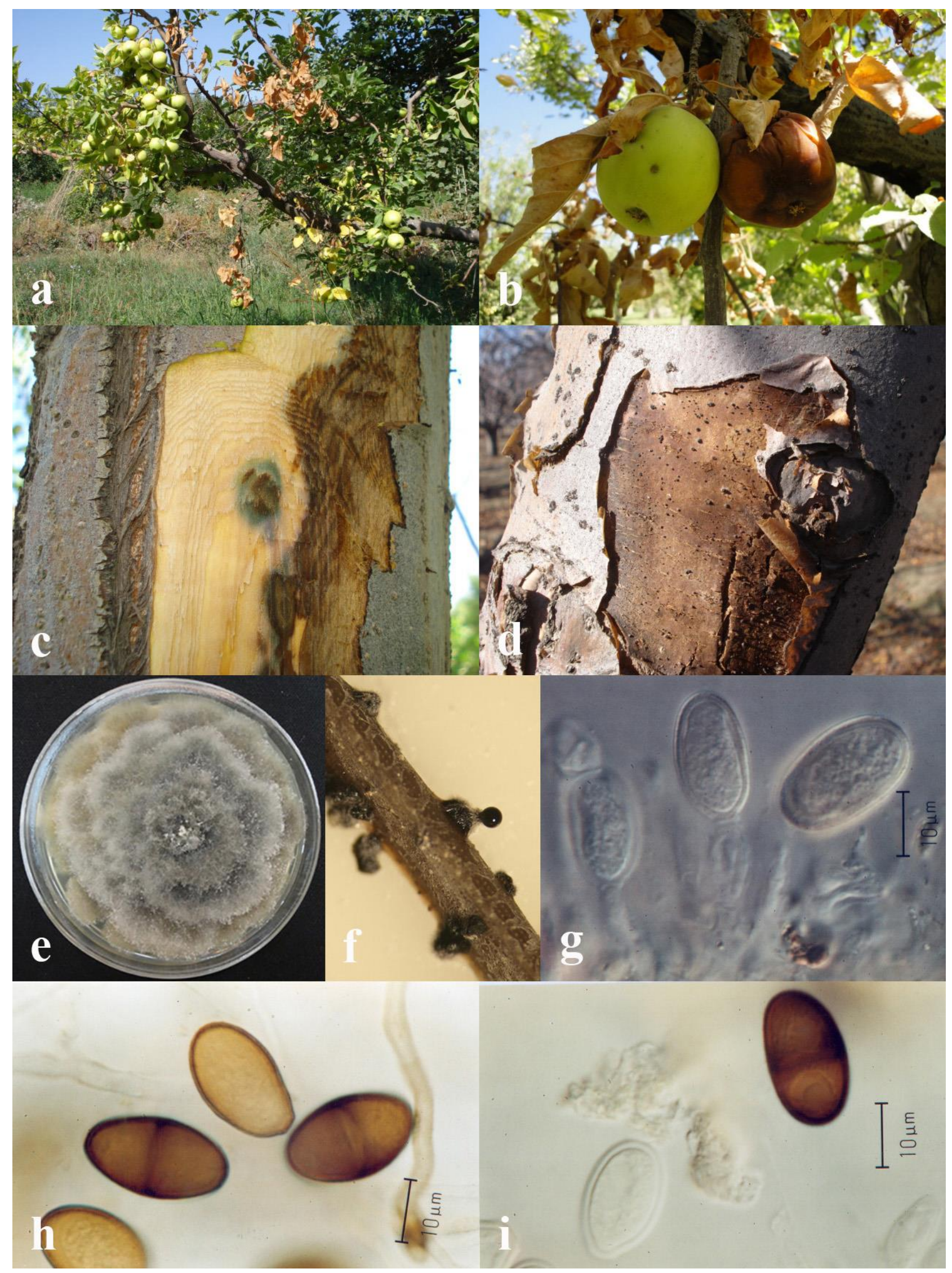

Figure 1 - Disease symptoms on Golden Delicious cultivar in apple orchards of Iran. a. Branch dieback. b. Fruit rot. c. Bark discoloration. d. Scaling-off of the bark. Morphological features of Diplodia bulgarica (IRAN 2727C). e. Colony on PDA. f. Pycnidia developing on pine needles in culture exuding conidia. g. Conidiogenous cells with developing conidia. h, i. Septate and aseptate conidia. Photographs by S Hanifeh. 


\section{Data analysis}

The experiments were randomized complete block design with three replications on 2-yearold seedlings in field conditions. After ANOVA, data on lesion length means were compared using SAS (ver. 9.2) analysis for Tukey's Studentised Range (HSD).

\section{Results}

\section{Symptoms in the field and identification}

Diplodia bulgarica causes stem and trunk cankers, dieback, bark discoloration, gummosis, scaling-off of the bark and fruit rot in the apple orchards of Iran (Fig. 1a-d). The colony was at first white, turned to olive green to olive gray after $3 \mathrm{~d}$ and finally became dark after two weeks. Pycnidia were globose to ovoid, dark brown to black. Conidia at first aseptate, ovoid to oblong, both ends broadly rounded, (19-29) $\times(12.5-17.5) \mu \mathrm{m}$ in diameter, initially hyaline, becoming pale brown, later darkening and becoming 1-septate before they were released from the pycnidia. Conidiogenous cells were hyaline, smooth, cylindrical, swollen at the base, 8-16 $\times 2.5-5 \mu \mathrm{m}$ in diameter, proliferating at the same level to produce periclinal thickening, or proliferating percurrently, giving rise to 1-3 annelations (Fig. 1e-i). All the isolates were identified as Diplodia sp. according to these morphological features. The nucleotide sequence of one isolate (GenBank Accession No. KY039060) had 100\% homology with Diplodia bulgarica isolates in GenBank (KF890211, JX152582, NR111444).

\section{Cultivars reaction trials}

Symptoms including necrosis, canker, discoloration of xylem and twig blight were observed in all of the tested cultivars (Fig. 2a-k). At the inoculation sites, brown necrotic lesions extended both upwards and downwards. In control treatments, no symptoms developed (Fig. 2).

Analysis of variance indicated that the mean lesion lengths differed significantly $(\mathrm{P}=0.01)$ between cultivars (Table 1). Severe symptoms were observed on Braeburn, Red Delicious, and Red Starking cultivars indicating that these are the most susceptible to D. bulgarica (Fig. 2a-c, e-g, k). The cultivars Qara Yapragh, Turkaman, and Golden Delicious had smaller lesions and were considered the least susceptible (Fig. 2d, h-j). The cultivars Granny Smith, Gala, and Golab were moderately susceptibility to D. bulgarica.

Table 1 Mean lesion length on apple cultivars after inoculation with Diplodia bulgarica (IRAN 2727C) evaluated under field conditions.

\begin{tabular}{lcc}
\hline Apple cultivar & Mean Lesion Length $\mathbf{( m m})^{\mathbf{1}}$ & Standard deviation \\
\hline Braeburn & $264^{\mathrm{a}}$ & 24.55 \\
Red Delicious & $248^{\mathrm{a}}$ & 22.50 \\
Red Starking & $245^{\mathrm{a}}$ & 21.51 \\
Granny Smith & $167^{\mathrm{b}}$ & 22.06 \\
Gala & $114^{\mathrm{bc}}$ & 17.34 \\
Golab & $112^{\mathrm{bc}}$ & 15.39 \\
Golden Delicious & $97^{\mathrm{c}}$ & 14.10 \\
Turkaman & $66^{\mathrm{c}}$ & 12.28 \\
Qara Yapragh & $59^{\mathrm{c}}$ & 13.65 \\
\hline
\end{tabular}

${ }^{\mathrm{l}}$ Mean of three replications.

Means followed by the same letters are not significantly different using Tukey's Studentised Range (HSD) Test $(\mathrm{P}=0.01)$. 


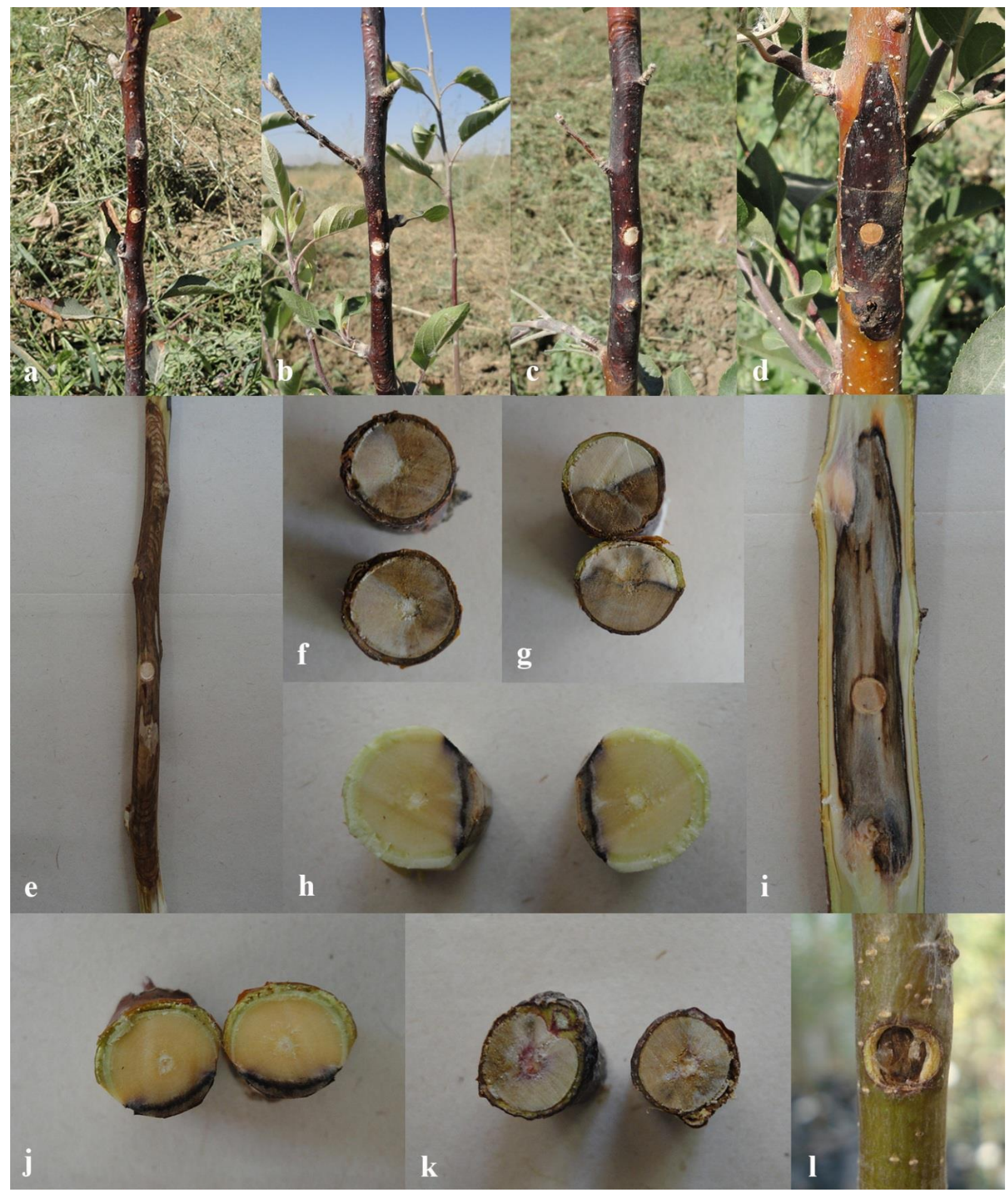

Figure 2 - Lesion symptoms on different apple cultivars. a. Red Starking. b, e. Braeburn. c. Red Delicious. d, i. Qara Yapragh. Progression of necrosis to vascular tissue of shoots. f. Braeburn. g. Red Delicious. h. Qara Yapragh. j. Turkaman. k. Red Starking. Control with callose. 1. Golden Delicious cultivar. Photographs by S Hanifeh.

\section{Discussion}

In the present study the reaction of nine apple cultivars to infection with $D$. bulgarica was assessed. All the tested cultivars developed disease symptoms with different severity. Based on other studies, responses of apple cultivars to Diplodia species including D. seriata could be different (Biggs \& Miller 2004, Borovinova 2006). D. seriata developed most canker area on 
shoots of Liberty and COOP 10 cultivars, while the least canker area was formed on Gala and Golden Delicious, while Granny Smith was recorded as moderately susceptible (Borovinova 2006). However, the results on fruits were slightly different, so that Granny Smith and Gala were showed the least rotted area and Golden Delicious was moderately susceptible (Borovinova 2006). In natural conditions, it was found that the rootstock had a strong effect on cultivars susceptibility, as the cultivars COOP 10, Granny Smith and Smoothy were more susceptible when grafted on M9 rootstock than on MM106 (Borovinova 2006). Also, the natural infection of apple buds to $D$. seriata was surveyed, but there were no significant differences among Red Delicious, Golden Delicious, Rome Beauty and Detroit Red cvs. (Beisel et al. 1984). Similar differences were observed among infestation levels of fruits by D. seriata, so that, cultivars Orin, Pristine and Sunrise were most susceptible, cultivars Creston, Golden Delicious, Enterprise, Gala Supreme, Braeburn, Gold Rush, and Fuji were the least susceptible, and the other cultivars were moderately susceptible (Biggs \& Miller 2004). Apple tree cultivars also had different responses to Botryosphaeria dothidea, with Red King Oregon as the most susceptible cultivar, and Granny Smith, Granny Smith Spur and Golden Delicious Spur were the least susceptible. The results indicated that the susceptibility of apple trunk was dependent on cultivar, isolate, and inoculation site (Latorre \& Toledo 1984).

Based on the results obtained from present survey, the largest lesions formed on Braeburn, Red Delicious and Red Starking and these were considered to be the most susceptible cultivars. Among the commercial cultivars, Golden Delicious was the least susceptible while Granny Smith and Gala showed moderate susceptibility to D. bulgarica.

Golden Delicious and Red Delicious are the main cultivars planted in apple orchards of Iran. So, given these findings, losses in apple orchards are not unexpected, and especially under drought and nutrient deficiency stresses, the trees showing more severe damage. These trees are more likely to be infected by Botryosphaeriaceae species than non-stressed trees (Slippers \& Wingfield 2007). In order to avoid these damages, management practices should be taken to reduce stress conditions. Also due to the lower susceptibility of local apple cultivars, it is suggested that further studies be carried out about breeding and introducing of commercial cultivars that are resistant to this pathogen in Iran.

\section{References}

Abdollahzadeh J, Hosseini F, Javadi A. 2013 - New records from Botryosphaeriaceae for mycobiota of Iran. Mycologia Iranica 1, 34-41.

Abdollahzadeh J. 2015 - Diplodia bulgarica, as a new pathogen and potential threat to the apple industry in Iran. Phytopathologia Mediterranea 54, 128-132.

Ahmadi K, Golizadeh H, Ebadzadeh H, Hoseinpour R et al. 2015 - Agricultural statistics (Volume 3). Ministry of Agriculture-Jahad, Tehran, Iran. http://www.maj.ir

Arzanlou M, Bakhshi M. 2012 - ITS-rDNA sequence differentiates a new lineage of Diplodia associated with canker disease of apple in Iran. Plant Pathology and Quarantine 2, 132-141.

Barr ME. 1987 - Prodromus to Class Loculoascomycetes. Published by the author, Amherst, Massachusetts.

Beisel M, Hendrix Jr FF, Starkey TE. 1984 - Natural inoculation of apple buds by Botryosphaeria obtusa. Phytopathology 74, 335-338.

Biggs AR, Miller SS. 2004 - Relative Susceptibility of Selected Apple Cultivars to Fruit Rot Caused by Botryosphaeria obtusa. Horticultural Science 39, 303-306.

Borovinova M. 2006 - Susceptibility of apple cultivars to Botryosphaeria obtusa. Notulae Botanicae Horti Agrobotanici Cluj-Napoca 34, 100-105.

Brown EA, Britton KO. 1986 - Botryosphaeria diseases of apple and peach in the Southeastern United States. Plant Disease 70, 480-484. 
Brown-Rytlewski DE, McManus PS. 2000 - Virulence of Botryosphaeria dothidea and Botryosphaeria obtusa on apple and management of stem cankers with fungicides. Plant Disease 84, 1031-1037.

Crous PW, Slippers B, Wingfield MJ, Rheeder J et al. 2006 - Phylogenetic lineages in the Botryosphaeriaceae. Studies in mycology 55, 235-253.

Delgado-Cerrone L, Mondino-Hintz P, Alaniz-Ferro S. 2016 - Botryosphariaceae species associated with stem canker, die-back and fruit rot on apple in Uruguay. European Journal of Plant Pathology 146, 637-655.

Denman S, Crous PW, Taylor JE, Kang JC et al. 2000 - An overview of the taxonomic history of Botryosphaeria, and a re-evaluation of its anamorphs based on morphology and ITS rDNA phylogeny. Studies in mycology 45, 129-140.

Dissanayake AJ, Phillips AJL, Li XH, Hyde KD. 2016 - Botryosphaeriaceae: Current status of genera and species. Mycosphere 7, 1001-1073.

Farr DF, Rossman AY. 2016 - Fungal Databases, Systematic Mycology and Microbiology Laboratory. ARS, USDA. http://nt.ars-grin.gov/fungaldatabases/. Retrieved June 10.

Foster HH. 1937 - Studies of the pathogenicity of Physalospora obtusa. Phytopathology 27, 803823.

Hanifeh S, Ghosta Y, Abbasi S. 2010a - Pathogenicity assessment of different Diplodia sp. isolates on Golden commercial cultivar of apple; $19^{\text {th }}$ Iranian Plant Protection Congress. Plant Protection Institute, Tehran, Iran.

Hanifeh S, Ghosta Y, Abbasi S. 2010b - Study and survey of main causes of apple trees decline in Western Azarbaijan province orchards; $19^{\text {th }}$ Iranian Plant Protection Congress. Plant Protection Institute, Tehran, Iran.

Hanifeh S, Ghosta Y, Abbasi S, Phillips AJL. 2013 - First report of Diplodia malorum Fuckel the causal agent of canker disease of apple trees in Iran. Iranian Journal of Plant Pathology 49, 83-84.

Hanifeh S, Ghosta Y, Abbasi S. 2014 - First report of Diplodia seriata, the causal agent of canker disease of apple trees in Iran. Iranian Journal of Plant Pathology 50, 103-104.

Ketabchi M, Ghosta Y. 2013 - Host range of Diplodia bulgarica, the causal agent of canker and bark gummosis of apple trees in West Azarbaijan Province; $1^{\text {th }}$ Iranian Mycological Congress. Guilan University, Rasht, Iran.

Latorre BA, Toledo MV. 1984 - Occurrence and relative susceptibility of apple cultivars to Botryosphaeria canker in Chile. Plant Disease 68, 36-38.

Laundon GF. 1973 - Botryosphaeria obtusa, B. stevensii, and Otthia spiraeae in New Zealand. Transactions of the British Mycological Society 61, 369-374.

Lazzizera C, Frisullo S, Alves A, Phillips AJL. 2008 - Morphology, phylogeny and pathogenicity of Botryosphaeria and Neofusicoccum species associated with drupe rot of olives in Southern Italy. Plant Pathology 57, 948-956.

Liu JK, Phookamsak R, Doilom M, Wikee S et al. 2012 - Towards a natural classification of Botryosphaeriales. Fungal Diversity 57, 149-210.

Nourian A, Safaie N, Abdollahzadeh J. 2013 - Report of Diplodia bulgarica and Neoscytalidium dimidiatum, the causal agents of apple canker in Western Azerbaijan and Isfahan provinces; $1^{\text {th }}$ Iranian Mycological Congress. Guilan University, Rasht, Iran.

Phillips AJL, Crous PW, Alves A. 2007 - Diplodia seriata, the anamorph of "Botryosphaeria" obtusa. Fungal Diversity 25, 141-155.

Phillips AJL, Lopes J, Abdollahzadeh J, Bobev S, Alves A. 2012 - Resolving the Diplodia complex on apple and other Rosaceae hosts. Persoonia 29, 29-38.

Phillips AJL, Alves A, Abdollahzadeh J, Slippers B et al. 2013 - The Botryosphaeriaceae: genera and species known from culture. Studies in Mycology 76, 51-167.

Proffer TJ, Jones AL. 1989 - A new canker disease of apple caused by Leucostoma cincta and other fungi associated with cankers on apples in Michigan. Plant Disease 73, 508-514. 
Sessa L, Abreo E, Bettucci L, Lupo S. 2016 - Botryosphaeriaceae species associated with wood diseases of stone and pome fruits trees: symptoms and virulence across different hosts in Uruguay. European Journal of Plant Pathology 146, 519-530.

Slippers B, Wingfield MJ. 2007 - Botryosphaeriaceae as endophytes and latent pathogens of woody plants: diversity, ecology and impact. Fungal Biology Reviews 21, 90-106.

Slippers B, Boissin E, Phillips AJL, Groenewald JZ et al. 2013 - Phylogenetic lineages in the Botryosphaeriales: a systematic and evolutionary framework. Studies in Mycology 76, 31-49.

Stevens NE. 1933 - Two apple black rot fungi in the United States. Mycologia 25, 536-548.

Trapman M, Maxin P, Weber RW. 2008 - Diplodia seriata, cause of black fruit rot in organically grown apples in Holland, Belgium and Northern Germany; $13^{\text {th }}$ International Conference on Cultivation Technique and Phytopathological Problems in Organic Fruit-Growing. Weinsberg, Germany.

Úrbez-Torres JR. 2011 - The status of Botryosphaeriaceae species infecting grapevines. Phytopathologia Mediterranea 50, S5-S45.

White TJ, Bruns T, Lee J, Taylor J. 1990 - Amplification and direct sequencing of fungal ribosomal RNA genes for phylogenetics. In: Innis MA, Gelfand DH, Sninsky JJ, White TJ. (eds) PCR protocols: a guide to methods and applications. Academic Press, San Diego, California, USA. 315-322. 